\title{
УДК 159.942:159.923-051
}

ПОДОЛЯК Наталія - кандидат психологічних наук, доцент кафедри практичної психології, Дрогобицький державний педагогічний університет імені Івана Франка, 24, вул. Івана Франка, м. Дрогобич, Украӥна, індекс 82100 (podolnatalya@gmail.com)

ORCID: https://orcid.org/0000-0002-1040-8080

DOI: https://doi.org/10.24919/2312-8437.45.196296

Бібліографічний опис статті: Подоляк, Н. (2019). Професійно значущі якості психолога в контексті проблеми емоційного вигорання. Проблеми гуманітарних наук: збірник наукових пращь Дрогобицького державного педагогічного університету імені Івана Франка. Серія «Психологія», 45, 89-99. doi: 10.24919/2312-8437.45.196296.

\section{ПРОФЕСІЙНО ЗНАЧУЩІ ЯКОСТІ ПСИХОЛОГА В КОНТЕКСТІ ПРОБЛЕМИ ЕМОЦІЙНОГО ВИГОРАННЯ}

Анотація. У статті подані результати емпіричного дослідження співвідношення показників емочійного вигорання та показників емпатї̈ та товариськості як професійно-значущих якостей особистості психолога.

У результаті теоретичного вивчення проблеми з'ясовано, що представники сочіономічних професій, до яких належить $i$ професія психолога, зазнають значного психоемочійного напруження. Така професійна діяльність потениійно містить небезпеку психотравмувальних ситуацій та ймовірність виникнення професійного стресу. 3 огляду на специфіку професії, психологи використовують власну особистість та ї̈ ресурси у професійній діяльності. Тому є доволі жорсткі вимоги до особистісно-професійних якостей фахівців изього профілю. Виявлено, щуо розвиток професійно-значущих якостей особистості психолога упродовж професійного навчання, може забезпечити ефективність його майбутньої професійної діяльності та створити певний ресурс самокерівництва і саморегуляиії.

Емпірична частина дослідження полягала у вивченні співвідношення між показниками емоційного вигорання, емпатї та товариськості як професійно значущими якостями особистості

(C) Подоляк Наталія, 2019 
психолога, оскільки саме їх дослідники виокремлюють як важливі для психолога-професіонала.

У результаті емпіричного дослідження за допомогою валідних та надійних діагностичних методик виявлено, щьо існують індивідуальні відмінності в емпатії та товариськості в осіб з різним рівнем емочійного вигорання. Емпірично встановлено, щчо для групи осіб з високим рівнем емочійного вигорання характерний низький рівень емпатії та товариськості. Особи з низьким рівнем емочійного вигорання характеризуються високим значенням загальної емпатії та товариськості. Доведено, що розвиток таких професійно важливих якостей, як емпатія та товариськість, мають певний вплив на рівень емоційного вигорання психолога.

Ключові слова: емочійне вигорання; емпатія; товариськість; професійно важливі якості; комунікативна компетентність.

PODOLYAK Nataliia - Candidate of Psychological Sciences, Associate Professor, Department of Practical Psychology, Drohobych Ivan Franko State Pedagogical University, 24 Ivan Franko Str., Drohobych, Ukraine, postal code 82100 (podolnatalya@ gmail.com)

ORCID: https://orcid.org/0000-0002-1040-8080

DOI: https://doi.org/10.24919/2312-8437.45.196296

To cite this article: Podolyak, N. (2019). Profesiino znachushchi yakosti psykholoha $\mathrm{v}$ konteksti problemy emotsiinoho vyhorannia [Professionally important qualities of a psychologist in the context of the problem of emotional burnout]. Problemy humanitarnych nauk: zbirnyk naukovych prats Drohobytskoho derzhavnoho pedahohichnoho universytetu imeni Ivana Franka. Seriia "Psykholohiia» - Problems of Humanities. "Psychology» Series: a collection of scientific articles of the Drohobych Ivan Franko State Pedagogical University, 45, 89-99. doi: 10.24919/2312-8437.45.196296 [in Ukrainian].

\section{PROFESSIONALLY IMPORTANT QUALITIES OF A PSYCHOLOGIST IN THE CONTEXT OF THE PROBLEM OF EMOTIONAL BURNOUT}

Abstract. The article presents the results of an empirical study of the relationship between indicators of emotional burnout and indicators of empathy and sociability as professionally significant qualities of the personality of a psychologist.

As a result of a theoretical study of the problem, it turned out that representatives of socionomic professions, which include the profession of a psychologist, are subjected to significant psycho-emotional stress. 
Such professional activities potentially contain a danger of traumatic situations and the likelihood of occupational stress. Given the specifics of the profession, psychologists use their own personality and its resources in professional activities. Therefore, there exist rather stringent requirements for the personal and professional qualities of specialists in this profile. The development of professionally significant qualities of the personality of a psychologist during vocational training can ensure the effectiveness of his future professional activity and create a certain resource for self-perception and self-regulation.

The empirical part of this research was to study the relationship between indicators of emotional burnout, empathy, and sociability as professionally significant qualities for the personality of a psychologist. For these are the qualities that researchers identify as important for a professional psychologist.

An empirical study using valid and reliable diagnostic techniques reveals that there are individual differences in empathy and sociability in people with different levels of emotional burnout. It has been empirically proved that people with a high level of emotional burnout are characterized by a low level of empathy and sociability. Those ones with a low level of emotional burnout are characterized by a high value of general empathy and sociability. It is proved that the development of such professionally important qualities as empathy and sociability have an impact on the level of psychologist's burnout.

Keywords: emotional burnout; empathy; sociability; professionally important qualities; communicative competence.

Постановка проблеми. Актуальність дослідження взаємозв'язку особистісних якостей психологів і синдрому емоційного вигорання зумовлена кількома чинниками. По-перше, реаліями сьогодення, що відзначаються високим рівнем запиту на психологічну допомогу, по-друге, необхідністю забезпечення фахової та кваліфікованої психологічної допомоги усім категоріям людей, що iï потребують i, по-третє, вимогами сучасної психотерапевтичної практики.

У психологічній літературі загалом наголошується на позитивних аспектах роботи людей, які задіяні в соціономічних професіях. Проте цілком очевидним видається і той факт, що саме така робота, пов'язана зі значними емоційними навантаженнями, висуває жорсткі вимоги до особистості фахівця, потенційно міс- 
тить у собі небезпеку психотравмувальних ситуацій і ймовірність виникнення професійних стресів.

Ціла низка науково-психологічних досліджень свідчить про те, що робота психолога насичена великою кількістю стресогенних чинників і їі можна вважати одним із найбільш емоційно напружених видів діяльності. Тому вона вимагає від фахівця володіння потужним ресурсом самокерівництва та саморегуляції (Л. Даниленко, Л. Карамушка, В. Орел, О. Старченкова, А. Фурман, О. Чебикін, В. Ямницький, С. Maslach та ін.) (Маслач, б.г.).

Окрім цього, психологи через особливості професійної діяльності користуються не лише власними знаннями, уміннями та навичками, але й використовують свою особистість у роботі i певною мірою беруть на себе функції «емоційного донора». Саме тому фахівцям у сфері психології, як і іншим працівникам системи «людина - людина», загрожує виникнення синдрому «емоційного вигорання».

Дослідники наголошують на тому, що труднощі у роботі психолога можуть бути пов'язані не лише з недостатністю знань, умінь і навичок, але й зі слабким розвитком професійно значущих якостей особистості.

Із огляду на ці міркування і виник інтерес до дослідження проблеми синдрому емоційного вигорання психолога у зв'язку 3 його професійними якостями.

Аналіз досліджень і постановка завдань. Дослідження феномену професійного вигорання, зокрема і в діяльності психолога, закономірно поставило на перший план питання про чинники, що сприяють його розвитку або навпаки гальмують його виникнення. Склалася традиція виокремлювати дві групи таких чинників: особливості професійної діяльності та індивідуальні характеристики професіоналів. Найчастіше ці чинники називають зовнішніми і внутрішніми або організаційними і особистісними, до того ж чинники взаємно підсилюють один одного (Маслач, б.г.).

Наприклад, В. Бойко серед особистісних чинників, що сприяють розвитку синдрому емоційного вигорання психолога, виокремлює насамперед схильність до емоційної холодності, інтенсивне переживання негативних обставин професійної діяльності, слабку мотивацію емоційної віддачі (Бойко, 1999). 
У цьому контексті значний інтерес мають дослідження проблеми розвитку професійно важливих якостей та становлення психолога-професіонала (Н. Амінов, О. Бодальов, С. Максименко, М. Молоканов, П. М'ясоїдов, В. Рибалка, В. Панок, Н. Повякель, Н. Чепелєва, Ю. Швабл, Т. Яценко та інші).

Аналіз наукової літератури дає підставу говорити про те, що важливими у структурі якостей психолога-професіонала $\epsilon$ його комунікативні якості. Ця проблема розглядається у роботах Б. Ананьєва, О. Бодальова, Н. Вишнякова, Дж. Гілфорда, А. Ільїна, У. Кала, В. Лабунської, Б. Ломова, В. Моляко, М. Обозова, Л. Петровської, О. Саннікової, П. Торренса та інших.

Здійснюючи аналіз професійно значущих якостей психолога, науковці найчастіше акцентують увагу на необхідності впевненості у собі, товариськості, ініціативності, психологічної проникливості, самоконгруентності, емоційності, оптимізму, соціального та емоційного інтелекту, емпатії, рефлексії, толерантності тощо.

Ці вимоги до фахівця можуть слугувати загальним орієнтиром і розглядатися як еталонні.

Отже, складність професійної діяльності психолога пов'язана 3 жорсткими вимогами, котрі ставить професія як до психофізіологічних особливостей фахівця-професіонала, так і до особистісних професійно важливих якостей. Тому дослідження взаємозв'язку особистісних якостей психолога з особливостями виникнення синдрому емоційного вигорання видається доволі актуальним.

Метою цієї є презентація результатів емпіричного дослідження співвідношення показників емоційного вигорання 3 показниками емпатії та товариськості як професійно значущих якостей психолога. Завдання дослідження - виявити та охарактеризувати специфіку емпатії та товариськості у осіб із різним рівнем емоційного вигорання.

Виклад основного матеріалу. Метою емпіричної частини дослідження було вивчення співвідношення між показниками емоційного вигорання, емпатії та товариськості як професійно значущими якостями особистості психолога.

Для розв'язання завдань дослідження підібрано комплекс психодіагностичних методик, що адекватні предмету дослідження: методика діагностики рівня емоційного вигорання В. Бойко; «Психодіагностичний модальнісний опитувальник емпатії» О. Сан- 
нікової, спрямований на діагностику емоційної, когнітивної, предикативної та дієвої емпатії; «Тест-опитувальник формальнодинамічних показників товариськості» О. Саннікової, призначений для дослідження таких параметрів товариськості, як потреба в спілкуванні, ініціативність, широта спілкування, легкість спілкування, стійкість і виразність у спілкуванні (Санникова \& Орищенко, 2001).

Емпіричне дослідження проводилося на базі факультету психології, педагогіки та соціальної роботи Дрогобицького державного педагогічного університету імені Івана Франка та загальноосвітніх шкіл м. Борислав. Вибірку склали студенти-магістри, які навчаються за спеціальністю «Психологія», «Практична психологія» та шкільні психологи. Загалом 53 особи.

На першому етапі був проведений кореляційний аналіз досліджуваних показників, у результаті якого були виявлені значущі кореляційні зв'язки між показниками емоційного вигорання, емпатії та товариськості.

Результати кореляційного аналізу між показниками емоційного вигорання та емпатії викладено в табл. 1.

Таблиця 1

\section{Результати кореляційних зв'язків між показниками емоційного вигорання та емпатії}

\begin{tabular}{|c|c|c|c|c|}
\hline \multirow{2}{*}{ Показники емпатії } & \multicolumn{4}{|c|}{ Показники емоційного вигорання } \\
\cline { 2 - 5 } & $\mathrm{H}$ & Рез & Всн & $3 \mathrm{~EB}$ \\
\hline $\mathrm{EE}$ & $411^{* *}$ & $419^{* *}$ & $201^{*}$ & $439^{* *}$ \\
\hline КЕ & & & $-193^{*}$ & $-121^{*}$ \\
\hline ПЕ & & & $-136^{*}$ & \\
\hline ДЕ & $265^{*}$ & & $312^{* *}$ & $292^{*}$ \\
\hline ЗПЕ & $303^{* *}$ & $201^{*}$ & & $276^{*}$ \\
\hline
\end{tabular}

Примітка: 1) коми та нулі опущено; 2) позначка ** свідчить про наявність кореляційних зв'язків на $1 \%$ рівні значущості, * - на $5 \%$ рівні; 3) умовні скорочення шкал емоційного вигорання: Н - напруження, Рез - резистенція, $\mathrm{BcH}$ - виснаження, ЗЕВ - загальний показник емоційного вигорання; 4) умовні скорочення шкал емпатії: $\mathrm{EE} \mathrm{-} \mathrm{емоційний} \mathrm{компонент} \mathrm{емпатії,} \mathrm{ДЕ} \mathrm{-} \mathrm{дійовий}$ компонент емпатії. 
Загальний показник емоційного вигорання має додатні зв' язки 3 показниками «емоційний компонент емпатії» (EE) на 1 \% рівні i «дійовий компонент емпатії» (ДЕ) «загальний показник емпатії» (ЗПЕ) на 5 \% рівні; від’ємний зв'язок із показником «когнітивна емпатія» на $5 \%$ рівні.

Також значущі кореляційні зв'язки виявлені при вивченні взаємозв'язків між показниками емоційного вигорання і товариськості. Результати кореляційного аналізу відображені у табл. 2.

Як видно 3 табл. 2, усі формально-динамічні показники товариськості мають статистично значущі зв'язки з показниками емоційного вигорання.

Таблиця 2

\section{Результати кореляційного аналізу}

між показниками емоційного вигорання і товариськості

\begin{tabular}{|c|c|c|c|c|}
\hline \multirow{2}{*}{$\begin{array}{c}\text { Показники } \\
\text { товариськості }\end{array}$} & \multicolumn{4}{|c|}{ Показники емоційного вигорання } \\
\cline { 2 - 5 } & $\mathrm{H}$ & Рез & В & $3 \mathrm{~EB}$ \\
\hline ПС & $158^{*}$ & $243^{* *}$ & & $134^{*}$ \\
\hline $\mathrm{I}$ & & $152^{*}$ & & \\
\hline Л & & $-172^{*}$ & $-262^{* *}$ & $-177^{*}$ \\
\hline $\mathrm{V}$ & & & $-182^{*}$ & \\
\hline $\mathrm{B}$ & $193^{*}$ & $311^{* *}$ & & $208^{* *}$ \\
\hline
\end{tabular}

Примітка: умовні скорочення шкал товариськості: ПС - потреба в спілкуванні, I - ініціативність, Ш - широта спілкування, Л - легкість спілкування, У - усталеність, стійкість, В - виразність в спілкуванні, ЗПТ - загальний показник товариськості.

Отже, отримані результати кореляційного аналізу дали можливість перейти до подальшого якісного аналізу.

Аналіз літератури та результати, що були отримані під час кореляційного аналізу, дали підставу припустити наявність особливостей прояву емпатії та товариськості в осіб із різним рівнем емоційного вигорання. Для виявлення цих особливостей був застосований метод «асів», за допомогою якого загальну вибірку $(\mathrm{n}=53)$ поділили на дві групи: особи з високим значенням загаль- 
ного показника емоційного вигорання $(\mathrm{EB}+, \mathrm{n}=14)$ та група 3 низькими значеннями загального показника емоційного вигорання (EB-, $\mathrm{n}=13)$.

Наступним кроком дослідження було визначення специфіки індивідуальних особливостей прояву емпатії та товариськості в умовно визначених групах (EB+) та (EB-). Для того, щоб вивчити особливості емпатії у представників із різним рівнем емоційного вигорання застосували метод «профілів», за допомогою якого були отримані профілі емпатії досліджуваних груп осіб, що зображені на рис. 1.

Тут і надалі середня лінія ряду проходить через 50-й процентиль. Значення, що лежать у площині вище середньої лінії ряду, характеризують високі показники досліджуваного феномену. Про яскраву виразність відповідного показника свідчать значення вище 75-ти процентилів; значення показників нижче середньої лінії ряду - про слабку вираженість або про невираженість (нижче 25-го процентиля) відповідних показників. Значення кожної позначки на графіку - це середнє арифметичне показників, що вивчаються. На осі ОX відкладені показники що вивчаються, на осі ОУ - значення показників виражене в процентилях.

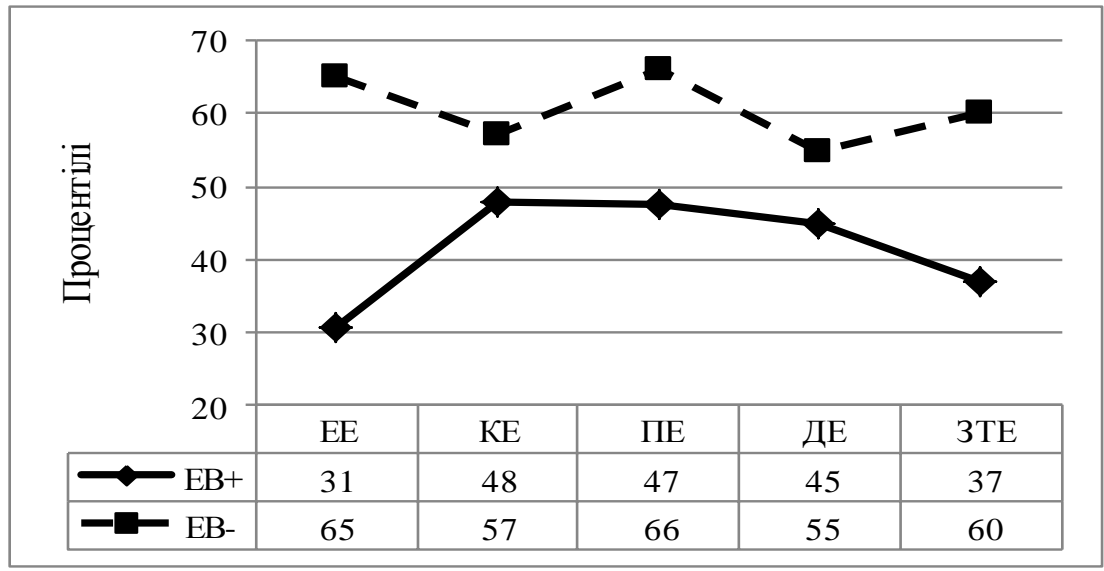

Рис. 1. Профілі емпатії осіб з високим (ЕВ+) та низьким (ЕВ-) рівнім емоційного вигорання 
Особи 3 низьким рівнем емоційного вигорання характеризуються високим значенням загальної емпатії, оскільки в них на достатньому рівні розвинуті всі якісні складові емпатії. Найбільш вираженим у цих осіб є показник ПЕ+ (предиктивна емпатія), а отже, вони здатні передбачати стан іншої людини в різних ситуаціях, можуть адекватно прогнозувати, як інша людина поведе себе в тих чи тих умовах. Також досить розвиненим у них $є \mathrm{EE}+$ (емоційний показник емпатії), що свідчить про здатність емоційно підключатися до іншої людини внаслідок чого можуть глибоко відчувати їі переживання.

Особи, що склали групу з високим рівнем емоційного вигорання характеризуються низьким рівнем загального показника емпатії (ЗПЕ-). Найменше у цих осіб виражені емоційні механізми (ЕЕ) та дійові аспекти емпатії (ДЕ), що відображені у відповідних якісних показниках цієї властивості. Також слабко виражені, хоча більше за інших наближені до середніх значень КЕ - (когнітивна емпатія) і ПЕ - (предикативна емпатія). У таких людей не виявляється здатність до співчуття, вони не можуть розуміти переживання іншої людини, передбачати реакції та прогнозувати психологічний стан і поведінку інших. Низький рівень дійової емпатії свідчить про нездатність надавати дієву підтримку іншій людині. Можна припустити, що емпатійне відображення у таких осіб відбувається у вигляді емоційного співпереживання та свідчити про наявність у цих осіб труднощів із глибоким розумінням індивідуальності іншого та $з$ його прийняттям.

Для вивчення особливостей прояву товариськості у осіб 3 високим та низьким рівнем емоційного вигорання нами були побудовані профілі формально-динамічних показників товариськості, результати яких зображено на рис. 2.

Аналіз профілів товариськості допоміг описати специфіку iii прояву в кожній досліджуваній групі.

Отже, представники групи з низьким рівнем емоційного вигорання демонструють високий рівень товариськості. Таким особам властиве активне ставлення та інтерес до світу та інших людей, здатність йти на контакт, зав'язувати нові знайомства, легко включатися в розмову з власної ініціативи.

Ці особи характеризуються схильністю до широкого кола спілкування, прагненням до великої компанії, швидкістю та 
легкістю вступу в контакт із незнайомими людьми, відчуттям комфорту в невідомій обстановці. Вони проявляють виразність міміки, пантоміми, динаміку рухів, змінюють інтонацію голосу, швидкість мовлення у процесі комунікації. Повною мірою використовують засоби виразного мовлення, демонструючи зовнішню виразність почуттів та емоцій, що виникають і виявляються у процесі спілкування. Їх можна назвати емоційно експресивними.

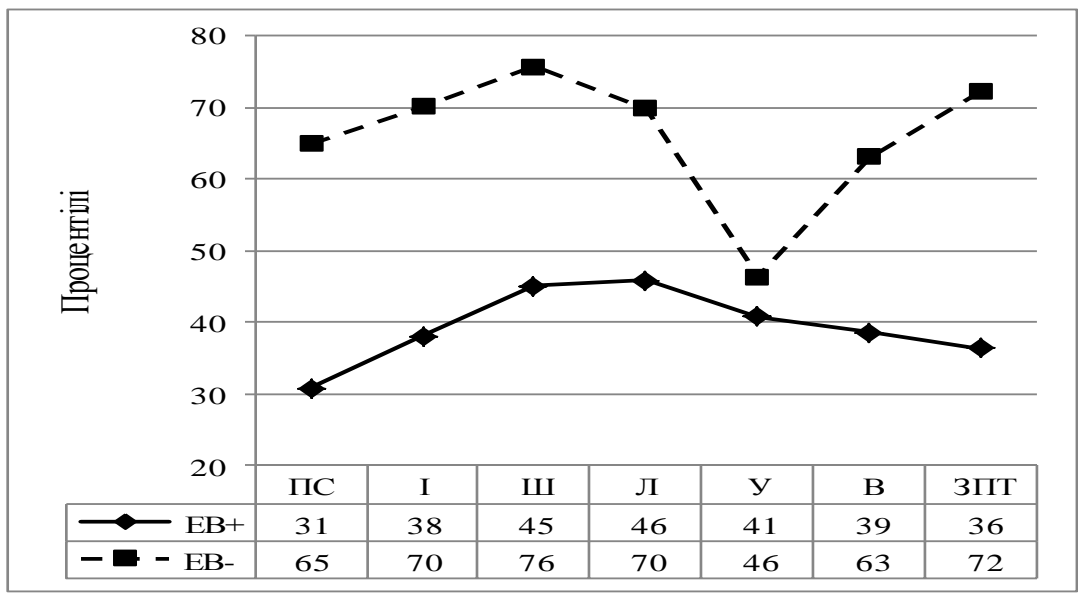

Рис. 2. Профілі товариськості груп осіб із високим та низьким рівнем емоційного вигорання

У представників групи осіб з високим рівнем емоційного вигорання усі параметри товариськості показують низькі значення. Таким особам притаманні труднощі вступу в соціальні контакти та в спілкуванні із незнайомими людьми. Для них характерною $є$ рідкість зав'язування знайомств, відсутність бажання проводити вільний час серед широкого кола людей та небажання підтримувати нові знайомства, вони не виявляють ініціативність у спілкуванні, не починають першими розмову 3 незнайомими людьми та не стають ініціаторами знайомств.

Висновки. Отже, можна стверджувати, що специфічними особливостями спілкування осіб, які переживають емоційне вигорання, $€$ труднощі в міжособистісних стосунках, наявність побоювань перед соціальним оточенням або неприйняття оточення. 
Можна припустити, що це пов'язано з емоційним перевантаженням стосунків та спробою кількісно та якісно їх зменшувати.

У результаті дослідження було виявлено особливості співвідношення показників професійно значущих комунікативних якостей особистості психолога 3 показниками емоційного вигорання. У перспективі дослідження цікаво було б розглянути, за яких умов емпатія та товариськість можуть сприяти виникненню синдрому емоційного вигорання.

\section{Література}

Бойко, В.В. (1999). Синдром «эмочионального выгорания» в профессиональном общении. Санкт-Петербург: Питер.

Долинська, Л.В. (2000). Забезпечення сучасних потреб освіти шляхом підготовки вчителя-психолога. Українська еліта та ї̈ роль у державотворенні: наукові записки, 1, 25-29. Київ.

Маслач, К. (б.г.). Профессиональное выгорание: как люди справляются. Взято с http://www.5ballov.ru/referats/preview/72429/6.

Санникова, О.П., \& Орищенко, О.А. (2001). Диагностика содержательных показателей эмпатии: апробация оригинального теста. Наука і освіта, 6, 54-57.

\section{References}

Boiko, V.V. (1999). Sindrom «emotcionalnogo vygoraniia»v professionalnom obshchenii [ «Burnout» syndrome in professional communication]. Saint Petersburg: Piter [in Russian].

Dolynska, L.V. (2000). Zabezpechennia suchasnykh potreb osvity shliakhom pidhotovky vchytelia-psykholoha [The provision of modern educational needs through training teacher psychologist]. Ukrainska elita ta yii rol u derzhavotvorenni: naukovi zapysky - Ukrainian elite and the role of the government: Science notes, 1, 25-29. Kyiv [in Ukrainian].

Maslach, K. (n.d.). Professionalnoe vygoranie: kak liudi spravliaiutsia [Professional Burnout: How People Cope]. Retrieved from http://www.5ballov.ru/referats/preview/72429/6 [in Russian].

Sannikova, O.P., \& Orishchenko, O.A. (2001). Diagnostika soderzhatelnykh pokazatelei empatii: aprobatciia originalnogo testa [Diagnosis of substantive indicators of empathy: testing the original test. Science and Education]. Nauka i osvita - Science and education, 6, 54-57 [in Russian]. 